\title{
Düşünceden Eyleme EOKA
}

\section{EOKA: From Thought to Action}

\author{
İsmail ŞAHİN ${ }^{1}$ [C]
}

'Doç. Dr., Bandırma Onyedi Eylül Üniversitesi, İktisadi ve İdari Bilimler Fakültesi, Uluslararası İlişkiler Bölümü, Balıkesir, Türkiye

\section{ORCID: I.Ş. 0000-0003-3144-7844}

\section{Sorumlu yazar/Corresponding author: \\ İsmail Şahin, \\ Bandırma Onyedi Eylül Üniversitesi, İktisadi ve İdari Bilimler Fakültesi, Uluslararası İlișkiler Bölümü, Balıkesir, Türkiye \\ E-posta/E-mail: \\ ismailshn@gmail.com}

Başvuru/Submitted: 29.04.2020

Kabul/Accepted: 05.05.2020

Atıf/Citation: Sahin, Ismail. (2020). Düşünceden Eyleme EOKA. Yakın Dönem Türkiye Araştırmaları-Recent Period Turkish Studies, 37: 21-49.

https://doi.org/10.26650/YTA2020-002

\section{ÖZ}

$\mathrm{Bu}$ çalışmanın amacı, EOKA'nın kuruluş sürecini Kıbrıs tarihinin önemli bir kısmını meşgul eden Enosis çerçevesinde incelemektir. Bugüne kadar bu örgüte yönelik kapsamlı ve yeterli ölçüde aka-demik çalışmaların yapılmamış olması, bu çalışmayı teşvik eden itici güç olmuştur. Çalışma, EO-KA'nın kuruluş fikrinin ortaya çıkışından ilk eylemini gerçekleştirinceye kadar ki örgütlenmesi ve faaliyetleri üzerine odaklanmıştır. Çalışmada Kıbrıs tarihinin önemli dönüm noktalarına da değinile-rek, makalenin konusunun daha kolay anlaşılmasına çalışılmıştır. Bu çalışma, EOKA'nın Enosis'i silah yoluyla gerçekleştirmek amacıyla kurulmuş paramiliter bir örgüt olduğu tezini savunmaktadır. Ayrıca EOKA'nın Kıbrıs Rum temsilcilerinin ve Yunanistan hükümetlerinin yürüttüğü Enosis diplo-masisinin başarısızlığı sonucunda meydana çıkmış bir örgüt olduğu araştırmada ortaya konulmak-tadır. Araştırma sırasında birinci el kaynaklar, arşiv belgeleri, konuya ilişkin makale ve kitapların yanı sıra gazetelerden de istifade edilmiştir.

Anahtar Kelimeler: Kıbris, EOKA, Enosis, Makarios, Grivas

\section{ABSTRACT}

The purpose of this study is to examine the establishment process of EOKA within the framework of other important events concerning the history of Cyprus. The fact that comprehensive and adequate academic studies have not been conducted on this organization until today, constitutes the reason for this study. The research focused on the historical period from the birth of EOKA's founding idea to its first action. Throughout the research, important turning points in the history of Cyprus were also men-tioned. Thus, it was thought that the subject of the article would be easier to understand. The article argues that EOKA is a paramilitary organization that was established to put into practice the enosis through weapons. It was revealed in the research that EOKA is an organization that emerged as a result of the failure of the enosis diplomacy of Greek Cypriot representatives and Greek governments. In the study, memoirs, archive documents, articles and books about the subject and newspapers of the period were used.

Keywords: Cyprus, EOKA, Enosis, Makarios, Grivas 


\section{Extended Abstract}

At the end of the Second World War, a fast decolonization process started in the British Empire. This situation re-triggered the sovereignty debate in Cyprus. Repre-sentatives of the Greek Cypriots had been trying to make Cyprus a territory of Gree-ce for many years. Enosis, which meant the annexation of the island to Greece, was a strong feeling among Greek Cypriots. They also wanted to take advantage of the decolonization process. However, Great Britain did not favor the annexation of the island to Greece due to its interests in the Middle East. Great Britain favored making a more libertarian constitution on the island instead of enosis. The Greek Cypriots responded to this approach of the British government by declaring that they would never step back from the enosis.

Enosis was not only prevented by Britain's interests in the Middle East. Tur-kish Cypriots were also strongly opposed to enosis. Because Turks living on other islands, especially in Crete, had to leave their homeland due to Greek pressure, they were concerned the same outcome would happen on their own. That is why the Tur-kish Cypriots defended the continuation of the British rule on the island, or it should have been given to Turkey, which was the former owner of the island. On the other hand, Turkey was also against enosis because Turkey saw the enosis as an instrument of the expansionist politics of Greece. Despite the Turkish Cypriots' and Turkey's objections, Greek Cypriots insisted on demanding Enosis.

The date of 18 October 1950 was a turning point for enosis because of Maka-rios III, whose original name was Mikhail Christodoulos Mouskos, was elected as archbishop. Makarios was ready to use all the facilities of the church for enosis. Eno-sis was a historical task, a national and religious issue for him. For that reason, he regarded leading the struggle for enosis as a great honor. According to Makarios, there were two ways to achieve enosis: diplomacy or armed struggle. He applied all the diplomatic methods he knew between 1950 and 1955. In this context, he organi-zed demonstrations in Athens and Nicosia; directed the public opinion, sought sup-port from the Greek lobby in the USA; and pressured the British administration.

All the diplomatic initiatives of Makarios and Greece failed to persuade Bri-tain for enosis. Therefore, Greece applied to the United Nations to obtain the right of self-determination for Cyprus on August 16, 1954. However, the United Nations rejected Greece's application. In the same period, besides diplomatic initiatives, an armed terrorist organization was established to carry out terrorist acts on the island, but this organization declined to take any action until the United Nations made its decision on Cyprus. The name of this 
organization was EOKA. It was founded under the leadership of retired Colonel Grivas and Makarios, and its aim was to carry out enosis through terrorist attacks.

The establishment activities of EOKA began secretly in 1951, and had comp-leted all preparations by 1 April 1955. EOKA carried out all its activities on the is-land mostly through youth organizations such as PEON and OHEN. The Cyprus Church provided financial support to EOKA. Thanks to this financial support, the necessary weapons could be purchased. In order to become a member of EOKA, it was necessary to be Greek, a supporter of enosis and not be a communist. Therefore, EOKA was a pan-helenic fascist organization whose purpose was limited to enosis. Consequently, EOKA cannot be described as an organization that is fighting against colonialism to gain independency for its own folk because it wanted only enosis, not national independence. It was clear that EOKA's motivation to resort to armed struggle against the British colonial administration was never independence. 


\section{Giriş}

Kıbrıs meselesi, 1950'lerin başından itibaren, Türk dış politikasının başlıca meselelerinden biridir. Türk kamuoyunun da başından beri büyük bir hassasiyetle takip ettiği bu meselenin lokomotifi ise Kıbrıs adasındaki Enosis taraftarlarıydı. Bu kişilerin amacı Kıbrıs adasını Yunanistan'a ilhak etmekti. Kıbrıs'taki Enosis davasını Yunanistan Krallığı'nın kuruluşuna kadar geriye götürmek mümkün gözükse de esas mücadelenin 1878 yılında adanın İngiliz idaresine girmesiyle başladığı söylenebilir. Kıbrıs’taki Enosis mücadelesinin iki aşamalı cereyan ettiği iddia edilebilir. Bunlardan birincisi barışçıl araçlarla yani diplomasi yoluyla bu hayali gerçekleştirme gayretlerinin egemen olduğu dönemlerdir. Kabaca bu dönem, 1878-1955 yılları arasına denk düşmektedir. İkincisi ise terör eylemleri marifetiyle Enosis’i hayata geçirme düşüncesinin hüküm sürdüğü yıllardır. Silah zoruyla Enosis’e ulaşma girişiminin ilk eylemi 1 Nisan 1955 tarihinde gerçekleşmiştir. Dolayısıyla ilk terör eyleminin yapıldığı tarihten Bağımsız Kıbrıs Cumhuriyeti'nin kurulmasını esas alan müzakerelerin başladığg tarihe kadarki dönem silah zoruyla Enosis kampanyasının birinci evresini oluşturur. Bu çalışmada sadece EOKA fikrinin doğuşundan örgütün ilk terör eylemini gerçekleştirdiği 1 Nisan 1955 tarihine kadar cereyan eden tarihi süreç değerlendirilmiştir.

\section{1. Örgütün Kuruluş Gerekçesi}

İkinci Dünya Savaşı'nın sona ermesiyle birlikte Kıbrıs'a yönelik egemenlik tartışmalarının yeniden alevleneceği beklenen bir durumdu. Savaş sonrasında Londra'da İşçi Partisi iktidara gelmişti ve Büyük Britanya İmparatorluğu'nu hızlı bir tasfiye sürecine tabi tutmaya başlamıştı. İngiltere'nin uğruna uzun savaşlar verdiği ve asla vazgeçmeyeceği iddia edilen Hindistan bile 1947 yılında bağımsızlığına kavuştu. İngiliz hükümetinin gündeminde Kıbrıs'1 bu tasfiye sürecine eklemek gibi bir düşünce yoktu. 23 Ekim 1946 tarihinde İngiliz Parlamentosu'nda yapılan bir münakaşada İngiliz hükümeti, Kıbrıs'taki herhangi bir egemenlik değişimine gidilmeyeceğini, adada kurucu bir meclis toplanarak içişlerinde, özgürlükçü ve ilerici bir rejimin yetkili kılınması için bir program hazırlayacağını belirtmişti. İngiliz hükümetinin bu tavrı, Rum temsilcilerini oldukça rahatsız etti.

Hindistan ve Filistin'in bağımsızlık tartışmalarının Londra gündemini meşgul ettiği siyasi bir havada, Kıbrıslı Rumlardan oluşturulan üç kişilik bir heyet, Birleşmiş Milletler'in kabul ettiği self determinasyon ilkesinin (ulusların kendi geleceklerini kendilerinin belirlemesi) "Kıbrıs halkına" tanınmasına ilişkin taleplerini iletmek üzere Şubat 1947 'de Londra'ya gitti. Heyet, 7 Şubat günü Sömürgeler Bakanı Arthur Creech Jones ile görüştü. Heyet görüşme sırasında din, dil, tarih ve milli bilinç bakımından 
Yunan olan ada için değişmez çözümün Enosis (Yunanistan ile birleşme) olduğunu; bunun haricinde hiçbir önerinin asla kabul edilmeyeceğini; adadaki Türk azınlığın haklarının korunacağını ve İngiltere'nin Doğu Akdeniz'deki çıkarlarının güvenliği konusunda Yunan hükümetinin gerekli kolaylıkları sağlayacağını sömürgeler bakanına ilettiler. ${ }^{1}$ Bakan Jones verdiği yanıtta İngiltere'nin Kıbrıs'ın statüsünde herhangi bir değişiklik tasavvur etmediğini, sadece adanın anayasal koşulları ile iktisadi şartlarını iyileştirici tedbirler üzerinde yoğunlaştığını, heyete bildirdi. İngiliz Hükümeti adada içişlerinde özgürlükçü, halk temsilcilerinin yönetim işlerine katılımını sağlayan daha liberal bir anayasayı yürürlüğe koymayı ve adanın sosyoekonomik açıdan gelişmesine katkı sunacak bir kalkınma programını hayata geçirmeyi planlıyordu.

Ancak Rum siyasi temsilcileri ile din adamlarının önderliğinde 16 Şubat günü, Lefkoşa'da İngiltere'nin teklifini protesto eden ve aynı zamanda Enosis'ten geri adım atılmayacağını beyan eden, binlerce kişinin toplandığı bir miting yapıldı. Mitingde dinleyicilere hitap eden Girne Piskoposu Makarios² konuşmasında, Yunanistan'ın savaş içinde İngiltere'ye büyük yardımlarda bulunduğunu ve İngiltere'nin Kıbrıs Rumlarının bu küçük arzusunu [Enosis] yerine getireceğini ümit ettiğini söyleyerek, "Kıbrıs'ın bize verilmesi Büyük İngiliz İmparatorluğu için hiçbir şey değildir.”’3 ifadelerine yer vermiştir. Protesto mitingi sonrasında toplanan kilise meclisi İngiliz hükümetince sunulan yeni anayasa ve kurucu meclis tekliflerinin kabul edilmeyeceği ve de tüm bu girişimlerin boykot edileceği yönünde bir karar aldı. Bunun yanında Rum temsilciler, 28 Şubat tarihinde İngiliz halkına hitaben, nihai kararlarının Enosis olduğunu bildiren bir kararname hazırladılar ve Yunan hükümetinden bu kararı İngiliz hükümetine iletmesini talep ettiler. Aynı tarihte Yunan Parlamentosunda oybirliğiyle alınan bir kararla 'Kıbrıs'ın Yunanistan'la birleşmesi” gerektiği belirtildi. ${ }^{4}$ Şubat ayında gerek Kıbrıs’ta gerekse de Atina'da yaşanan Enosis hareketliliğinin en önemli motivasyonu, kuşkusuz, 10 Şubat 1947 tarihinde imzalanan Paris Barış Antlaşması ile Rodos, Oniki Ada ve Meis'in Yunanistan'a devredilmesiydi. Antlaşma öncesinde Kıbrıs Rum halkı gibi bu adaların Rum halkı da İngiltere ve Amerika devlet yetkililerine telgraflar yollayarak Yunanistan ile birleşme isteklerini dile getiriyorlardı. Nihayetinde İngiltere, hem Kıbrıs’taki Enosis

1 George Hill, Kıbrıs Tarihi 1571-1948, çev. Nazım Can Serbest, İstanbul, İş Bankası Yayınları, 2016, s. 483.

2 Girne Piskoposu Makarios Myriantheus ateşli bir enosis taraftarıydı. 1931 yılında patlak veren isyanın müsebbipleri arasında görüldü ve sürgüne gönderildi. Sürgün cezası 1946 yılının sonlarına doğru kaldırıldı ve ardından adaya döndü. Başpiskoposluk seçimlerine kadar, bu makamı locum tenens sıfatıyla vekâleten yürüttü. Ekim 1947'de II. Makarios olarak Kıbrıs Ortodoks Kilisesi Başpiskoposluğuna seçildi. Dolayısıyla Kıbrıs tarihine damgasını vuran III. Makarios ile karıştırılmamalıdır.

3 Hürsöz Gazetesi, 17 Şubat 1947.

4 George Hill, Kıbris Tarihi, s. 483-484. 
konusundaki istekleri asgariye indirmek, hem de savaş boyunca ağır bedeller ödeyen Yunanistan'ı ödüllendirmek maksadıyla Oniki Ada'nın Yunanistan'a verilmesi için gereken tüm desteği verdi. Ancak, İngilizlerin düşündüğünün tam aksi istikamette, Oniki Ada'nın Yunanistan'a bırakılmasının Kıbrıs ve Atina'daki Enosis arzusuna körükleyici bir etki yaptığı söylenebilir.

Adanın Rum temsilcileri, Kıbrıs'ta İngiliz idaresi başladığı günden itibaren hiç olmadığı kadar Enosis konusunda umutlandılar. Yunanistan'ın bağımsızlığını kazanmasında ve topraklarını genişletmesinde İngiltere'nin oynadığ 1 tarihi rolden hareketle, İngilizlerin benzer şekilde Kıbrıs'ın Yunanistan toprağı olması için gerekeni yapacağını ümit ediyorlardı. Bu doğrultuda, 1878 yılından beri mütemadiyen İngiliz hükümetine yazılı dilekçeler verilmiş ve Enosis konusunda hem İngiliz kamuoyunu hem de hükümetini ikna edebilmek amacıyla birçok heyet Londra' ya gönderilmişti. Tüm bu girişimler başarı ile başarısızlık arasında gidip gelmiş; İngiliz kamuoyu ve siyaset adamları tarafindan Enosis bazen şiddetle desteklenmiş bazen de şüpheyle karşılanmıştır. Ancak hemen belirtmek gerekiyor ki sömürgeler bakanlığı ile genelkurmay başkanlığının, bakanlar kuruluna vermiş oldukları yazılı görüşlerde, Kıbrıs'ın İngiltere'nin Akdeniz ve Ortadoğu'daki bütünleşik çıkarlarından dolayı elde tutulması şiddetle tavsiye edilmiştir.

İngiltere’yi 1878 yılında Kıbrıs'a yönlendiren faktör ortaya çıkan Rus tehlikesiydi. Fakat sonraki yıllarda böyle bir tehlike gün yüzüne çıkmadı. O yüzden Londra yönetimi, adaya gerekli askeri yatırımları yapmayı uygun görmedi. Bu bağlamda İngiliz donanmasına üs vazifesi sunacak bir limanın inşası gereksiz bir harcama olarak değerlendirildi. 1945 öncesinde askeri uzmanlar Süveyş’teki üslerin yeterli olduğu kanısındaydı. Ayrıca Filistin'in hâkimiyetinin kendi ellerinde olmasını askeri açıdan ek bir güvence şeklinde yorumluyorlardı. Bu nedenle Kıbrıs adası, İngiliz İmparatorluğu'nun güvenliğine doğrudan bir katkı sunmuyordu ve bundan dolayı bu durum, Londra'da daima tartışma konusu oluyordu. Başka bir ifadeyle bazı devlet adamları adanın egemenliğini elinde bulundurmanın gereksiz bir maliyet olduğu düşüncesindeydi. Tüm olumsuz düşüncelere rağmen Londra'daki hâkim görüş, adanın başka bir gücün eline geçmesini önlemekti. Zira Kıbrıs'ın Levant bölgesindeki stratejik değeri yüksekti ve başka bir güç tarafından İngiltere'ye karşı kullanılabilirdi. Bu yüzden adanın hâkimiyet altında tutulmasının yaratacağı caydırıcılığın bile imparatorluk için vazgeçilmez bir önemi vardı.

1948 yılında koşullar değişti. İngiltere'nin Filistin'den tümüyle çekilmesiyle birlikte Kıbrıs Doğu Akdeniz bölgesinde İngiliz egemenliği altında kalan tek toprak parçası haline geldi. Süveyş Kanalı bölgesindeki İngiliz üslerinde İngiliz hâkimiyetinin ne kadar 
süreyle devam edeceğine ilişkin endişeler, savaş sonrasında güçlenen Arap ulusçuluğu ve Nasır hareketi ile üst düzeye çıtı. İngiltere'nin Süveyş’ten de uzak olmayan bir gelecekte çekileceğine dair işaretler artık kendini belli ediyordu. Dahası bu belirsiz siyasi ortamda İngiltere'nin kendi ulusal çıkarlarının emniyetini henüz garantiye alamadığı biliniyordu. Özellikle bölgedeki uluslararası ticaretin güvenliği ile Ortadoğu petrollerindeki yatırımları kaygı uyandıran başlıca meselelerdi. Dolayısıyla İngiliz devlet adamları değişen şartlar çerçevesinde Kıbrıs'1 yeniden değerlendirmeye tabi tuttular. İkinci Dünya Savaşı yerini Soğuk Savaş'a terk etmişti ve yakın bir süre önce müttefik safındaki Sovyetler Birliği (SSCB) yeni bir düşman olarak uluslararası statükoyu tehdit ediyordu. Öyle ki İngiliz askeri uzmanlar, imparatorluğun Ortadoğu' daki çıkarlarına yönelebilecek tek ciddi askeri tehdidin, Sovyetler Birliği'nden gelebileceği üzerinde duruyorlar ve bu hususta hükümetlerini sıklıkla uyarıyorlardı.

$\mathrm{Bu}$ aşamada İngiltere'nin Enosis'e evet demesinin, kendi stratejik menfaatleri açısindan tutarlı ve sağlam bir karar olmayacağı ifade ediliyordu. Bilhassa sömürgeler bakanlığı ve genelkurmay başkanlığı bu görüşü ısrarla savunan kurumların başını çekiyordu. Bu kurumlar, yaptığı uyarılarda bir taraftan adanın limanlarının büyük tonajlı gemiler açısından uygun olmadığının altını çizerken diğer taraftan adanın Doğu Akdeniz'de güvenliği tesis edebilecek nitelikte düşük tonajlı savaş gemilerine müsait limanlara ve hava kuvvetlerinin üs olarak kullanabileceği uygun alanlara sahip olduğu ifade ediliyordu. Ayrıca adada kurulacak radar istasyonlarının askeri strateji yönünden İngiliz kuvvetlerine sunacağı avantajların kayda değer bir öngörü ve istihbarat sağlayacağı belirtiliyordu. ${ }^{5}$ Yukarıdaki jeopolitik hesaplamalardan ötürü İngiliz yönetimi Enosis fikrine sıcak yaklaşmadı. Bununla birlikte toplumdaki Enosis arzusunun şiddetinin k1rılması gerekiyordu. İngiliz yöneticiler şöyle bir karara vardılar. Buna göre, şayet adanın refahı ve anayasal temsiliyeti iyileştirilirse, öncesinde işgal sonrasında da iç savaş nedeniyle iktisadi, siyasi ve toplumsal açılardan büyük bir çöküş yaşayan Yunanistan ile birleşme fikrinden adanın Ortodoks cemaati en azından kısa bir süreliğine vazgeçebilirdi. Böylelikle İngiltere, bir süre daha egemenliğini ve askeri varlığını adada güven içerisinde devam ettirebilirdi.

Londra ve Kıbrıs'ta görev yapan İngiliz yöneticiler ile memurlar, Rumların Enosis isteklerini büyük bir şaşkınlık içerisinde izliyorlardı. Onların gözünde Yunanistan, yönetim, asayiş, eğitim ve mali haklar bakımından kötü koşulların hüküm sürdüğü bir ülkeydi. Adadaki Rum sakinlerin böylesine olumsuz şartlara sahip bir ülkeyle birleşmek istemesi, İngilizlere

5 Şükrü S. Gürel, Kıbrıs Tarihi (1878-1960) 2, İstanbul, Kaynak Yayınları,1985, s. 36. 
ziyadesiyle mantık dışı geliyordu. Ancak İngilizler, çok önemli bir noktayı ya görmezlikten geliyorlardı ya da fark edemiyorlardı. Bir defa İngilizler, başından beri adayı eğreti bir şekilde ellerinde tutmuşlar ve bundan dolayı adaların sosyoekonomik sorunlarıyla çok fazla alakadar olmadılar. Eski düzeni muhafaza etmenin pek ötesine geçemediklerini iddia etmek mümkündür. Daha kötüsü, İngilizler ne adanın Müslüman ne de Hristiyan halklarıyla kaynaşabildiler. Onlara aşağı ırk gözüyle muamele etmeyi tercih ettiler. İngilizlerin entelektüel birikimlerinin kökeninde Greko-Romen miras ağır basıyordu ve başlangıçta adanın Rumlarına Antik Yunan'ın torunları nazarıyla yaklaşmışlardı. Zaman içerisinde yanıldıklarını ve onların gerçekten bir Yunan olmadığına kanaat getirdiler. Hatta bazılarına göre adanın Rum sakinleri Anadolu meleziydi. İddiaları her ne olursa olsun, adanın İngiliz yöneticileri, memurları ve onların ailelerinin Kıbrıs halkına bakışları incitici ve aşağılayıcıydı. İngiliz yönetiminin büyük bölümü toplumsal statü gösterişleriyle geçti denilebilir. Kendilerinin üstün bir ırk olduğunu düşünen İngilizler, inşa ettikleri o seçkin hayatın içerisinden adanın gerçek sorunlarını idrak edemediler. Sosyo-ekonomik sorunlar bir kenara, büyümekte ve yayılmakta olan Enosis tehlikesini bile küçümsediler. Ta ki 1931 yllında meydana gelen isyana kadar. İngiliz memurların zannettiği gibi Enosis fikrinin ardında bir avuç fanatik solcu ile birkaç bağnaz din adamı bulunmuyordu. Enosis siyasi bir idealdi ve adadaki sosyo-ekonomik şartlar her geçen gün bu idealin güç kazanmasına hizmet ediyordu.

Zaman içerisinde Rum politikacılar, aydınlar, gazeteciler, öğretmenler, din adamları ve önde gelen iş adamları elbirliğiyle Enosis'i milli bir talebe dönüştürmeyi başardılar. Ve bu taleplerinin dışında kalan herhangi bir çözümü asla kabul etmeyeceklerini defaaten İngiliz yetkililere yazılı ve sözlü bir şekilde ilettiler. Enosis, Megali İdea'nın (Büyük Ülkü) bağrından çıkmış bir düşünceydi ve ilk kez Girit'in Yunanistan'a dâhil edilmesi sırasında işitilir olmuştu. Yunanca'da birleşme manasına gelen kavram Balkan Savaşları sırasında da sıklıkla duyuldu. En geniş anlamıyla Enosis, "Büyük Yunan Milli Devleti" hayalini gerçekleştirmek için takip edilen Megali İdea politikası kapsamına alınan toprakların teker teker Yunanistan'a katılmasını sağlama girişimidir. Özel olarak ise, yaklaşık bir asırdır, Pan-Helenik ideallerin bir uzantısı olarak Kıbrıs adasının Yunanistan ile birleşmesi anlamında kullanılmaktadır. Kıbrıs, iç ve dış siyasetini şekillendiren en önemli politik faktör olan Enosis'ti. Bunun yanında Kıbrıs ve Yunanistan'da bulunan kilise temsilcileri Enosis'e dini bir anlam yüklemekten geri durmuyordu.

Enosis, orta sınıftan gelen okumuş kişiler arasında yaygın olmakla birlikte bu hareketin başını Kıbrıs Rum toplumu içindeki en önemli iki güç odağı olan kilise ile AKEL ${ }^{6}$ 
çekiyordu. Bu iki kurumun çevresinde toplanan Enosis hareketi, barındırdığı tutku ve ülkü sayesinde taraftarlarını kanlı bir çarpışmaya sürükleyebilecek düzeyde etkiliydi. Kilise, Rum cemaatinin en örgütlü ve en köklü kurumuydu. Osmanlı İmparatorluğu döneminde elde ettikleri "milletbaşı" yetkisiyle adadaki Ortodoks cemaatin hem siyasi hem de dini temsilcisiydi. Bu hakkı başpiskoposlar etkin bir şekilde icra ederek kilisenin iktidar alanı$\mathrm{n} 1$ genişlettiler. Bugün dahi ruhani ve politik açıdan kilisenin Rum toplumu üzerindeki keskin otoritesini gözlemlemek mümkündür. Son tahlilde kilisenin, Enosis kıvılcımının büyük bir yangına dönüşmesindeki payı yadsınamaz bir gerçektir.

Benzer biçimde İkinci Dünya Savaşı sırasında ve sonrasında Kıbrıs Rum solunun da etkin bir Enosis kampanyası yürüttüğ̈̈ görülmektedir. AKEL, 14 Nisan 1941 tarihinde kuruldu. 7 İşçi hareketleri, sendikal faaliyetler, mesleki örgütlenmeler ve sosyalist ideolojinin propagandası başlıca etkinlik alanlarıydı. Adadaki sol örgütlenmelerin ve iş̧̧i hareketlerinin merkezi konumundaki AKEL'in başlica rakibi kiliseydi. Öyle ki bu iki kurum arasındaki rekabetten dolayı 1943 yılında Kıbrıs Rum sendikaları milliyetçi ve solcu olmak üzere ikiye ayrıldı. Sömürgeciliğe karşı mücadelede işçileri, memurları, tarım çalışanlarını, zanaatkarları ve aydınları örgütlemeye çalışan AKEL, aynı zamanda anti-sömürgeci ve anti-emperyalist bir yönü de bulunan Enosis'i olabildiğince sahipleniyor ve onu kilisenin tekeline bırakmamak için keskin bir mücadele veriyordu. Nitekim 31 Ekim 1943 tarihinde Londra'da düzenlediği Kıbrıs Konferans1 adlı etkinlikte, "Kıbrıs'ın ulusal sorunu, ancak ada halkının büyük çoğunluğunun anavatanı olan Yunanistan'la birleşme gerçekleştirilerek çözülebilir" "şeklinde bir karar alarak niyetini açıkça ortaya koyuyordu. Enosis konusunda her iki kurumun 1960 ertesine kadar açık bir şekilde rekabet halinde olduğu rahatlıkla ifade edilebilir. Sonuçta Kıbrıs adasının ortak dil, din, tarih, toprak ve köken bakımından Yunan olduğu ve bu yüzden anavatan Yunanistan ile birleşmenin vakit kaybetmeden gerçekleşmesi yönünde bir fikir birliği, yukarıdaki kurumların marifetiyle ada genelinde oluştu.

1950'li yılların başında Enosis Kıbrıs hayatının temel öğesiydi ve Rumların neredeyse tamamı Enosis taraftarıydı. Radyolar, gazeteler, kahvehaneler, okullar, siyasi partiler, dernekler ve lokaller mola vermeksizin bu konu üzerine konuşuyordu. Benzer biçimde Atina Radyosu da adadaki atmosferi ısıtan kışkırtıcı yayınlar yapmaktan geri durmuyordu. Beyaz badanalı evlerin duvarlarına yazılan Enosis yazıları neredeyse adanın bir ucundan diğer ucuna gözlemlenebiliyordu. Bugün bile tamirat görmemiş köy

7 Akel'e ilişskin daha geniş bir bilgi için bkz. T. W. Adams, The Communist Party of Cyprus, Stanford, Hoover Institution Press, 1971.

8 Şükrü S. Gürel, Kıbrıs Tarihi, s. 15-16. 
evlerinin duvarlarında silinmeye yüz tutmuş bu yazıları görmek mümkündür. Ada genelinde yapılan gösteriler, boykotlar ve grevlere rağmen insanların çoğunun aklında İngilizlere karşı şiddet eylemlerine başvurma düşüncesi bulunmuyordu. Çoğunluk, diplomasi ve diğer barışçıl araçlarla bu işin çözüme kavuşturulacağını umuyordu.

Ancak Enosis gerçekte rasyonel temelden uzak bir düştü. Fakat bu konunun mantıklı bir şekilde ele alınıp tartışılmasına Rum basını, kilise temsilcileri, siyasetçiler ve diğer demagoglar müsaade etmiyordu. Bir defa Enosis'çiler Kıbrıs Türklerini hiç hesaba katmıyorlardı ve onları sadece basit ve küçük bir azınlık olarak tanımlamakla yetiniyorlard1. Yine olası bir Enosis durumuna Türkiye'nin nasıl tepki vereceği dikkate dahi alınmıyordu. Kıbrıs Türkleri Enosis lafzının dolaştığı ilk günlerden beri bu fikkre karşı olduklarını her platformda dile getirmekten geri durmadıkları gibi, Türkiye'de tahsil gören, çalışan veyahut daimî surette yaşayan Kıbrıs Türkleri vasıtasıyla 1948 yılında Türk kamuoyunun Kıbrıs'a ilgi duymasını başarmışlardı. Türk kamuoyunun ve Kıbrıs Türklerinin tüm itirazlarına rağmen Grivas ve Makarios'un başını çektiği bir grup Enosis taraftarı, diplomasi ve barışçıl araçlarla Enosis'in gerçekleşmeyeceğine ve bu davanın ancak silah yoluyla kazanılabileceğine ikna olduklarında takvimler 1 Mayıs 1951 'i gösteriyordu.

\section{2. Örgütün Kuruluş Amacı}

EOKA $^{9}$, Enosis’i gerçekleştirmek amacıyla Grivas, Makarios ve Yunan Hükümeti iş birliğiyle kurulmuş silahlı bir örgüttü. Helenizm, anti-Komünizm ve irredantizm ${ }^{10}$ bu örgütün temel fikirlerini oluşturuyordu. Enosis için Kıbrıs’ta barışçıl mücadele olanaklarının tüketilmiş olduğu düşüncesi EOKA'nın ana teziydi. Örgütün kuruluş amacı, yaptığı silahlı eylemlerle dünyanın dikkatini Kıbrıs'a çekmek ve Birleşmiş Milletler'in İngiliz sömürgesinde yaşayan Kıbrıs halkına self determinasyon hakkını bir çözüm olarak sunmasını sağlamaktı. İngiltere ile Yunanistan arasında adanın devrine ilişkin bir anlaşmanın gerçekleşme ihtimali görünür olmadığı için bu süreçte uluslararası hukuk açısından en makul çözüm self determinasyon hakkının elde edilmesi ve ardından yapılacak bir plebisit ile Enosisi gerçekleştirmekti. Dolayısıyla örgütün esas amacı Enosisti ve uluslararası hukukun temel ilkelerinden biri haline gelen self determinasyon hakk1 Enosis kapısını açabilecek tek anahtardı. Örgütün tüm kurgusu bu basit hesaba dayanıyordu. Yunanistan, Avrupa, Amerika ve Kıbrıs’tan Enosis düşüncesini kabul eden çok sayıda asker, avukat, akademisyen, gazeteci, politikacı ve din adamı bu örgütün

9 Ethniki Organosis Kyprion Agoniston: Kıbrıslıların Millî Mücadele Örgütü.

10 Soydaşların yaşadığı yerleri kendi sınırlarına katma fikri. 
kurulmasına ve dünya çapında kamuoyu yaratmasına maddi ve manevi destek verdi. Daha önemlisi EOKA başlatacağı silahlı eylemlerde yerel halkın tam desteğine güveniyordu. Zira halkla tam bir iş birliği sağlanmadan ne yoğun bir kitle çalışması yürürlüğe sokulabilir ne de örgüt mutlak bir gizlilik içinde tutulabilirdi.

EOKA, İngilizleri Enosis'e ikna edebilmek amacıyla iki koldan yıldırma ve yıpratma stratejisi sürdürmeyi planlıyordu. Bunlar kırsalda gerilla savaşı; şehirlerde sabotajlar yapmaktı. Her iki silahlı eylemin nihai hedefi adada hayatı her yönüyle felce uğratmak ve sömürge idaresini dize getirmektir. Silahlı eylemlerin yanı sıra bir diğer önemli araç, kitleleri harekete sevk etmeye yönelik çalışmalar yapmaktır. Bu doğrultuda EOKA'nın bilhassa gençlik teşkilatlarındaki kişilerin zihinlerindeki Enosis idealini ateşlediği ve onları kitlesel eylemlerde kullandığı görülmektedir. Nitekim öğrenciler arasında uğrunda mücadele ettikleri özgürlük duygusu gibi daha soyut düşüncelere rastlanır. Buradaki gaye, dünya kamuoyunu etkilemede öğrencilerin mühim bir rol oynayacaklarını düşünmeleriydi. ${ }^{11}$ Enosis önderlerine göre, İngiltere'yi Kıbrıs’ta devam eden sömürge rejiminin iflas ettiğine ikna etmek gerekiyordu. Fakat bu ikna edici eylem, 1931 isyanından farklı bir içeriğe sahip olmalıydı. Nihayetinde EOKA'nın bunu sağlayabileceğini umuyorlard1. ${ }^{12}$ Örgütün dikkat çeken eylemleriyle uluslararası kamuoyunu ve İngiltere'nin kendisini, Kıbrıs'ın sömürge baskısı altında bulunduğuna ve halkın arzu ettiği çözümün Enosis olduğuna inandırabilirlerdi.

\section{3. Örgütün Mimarları: Makarios ve Grivas}

\subsection{Makarios}

Mikhail Christodoulos Mouskos ${ }^{13}, 13$ Ağustos 1913 tarihinde Trodos dağlarının eteklerinde Baf kentine bağl1 Panayia köyünde, fakir bir ailenin çocuğu olarak dünyaya geldi. Babası çobandı. 1926 yılında ilkokulu bitirdikten sonra üç yaşında papaz adayı olarak yemyeşil bir dağ zirvesinde yer alan Cikko (Kykkos) Manastırı'na girdi. Burası adanın en büyük ve en ünlü manastırıdı. On iki yıl boyunca burada eğitim aldı ve hemen ardından I938'de yardımcı papazlığa atandı. Aldığ 1 yüksek tahsil bursuyla Atina Üniversitesi'nde teoloji okumaya gönderildi. Atina'daki üniversite öğrenciliği Alman işgaline denk gelmiş olmasına rağmen I942'de üniversiteden mezun olmayı başardı. 1946 yılına kadar Atina'da kaldı ve bu arada St. Irene Kilisesi'nde görev yaptı. İki

11 Lawrence Durrell, Kıbrıs'ın Acı Limonları, çev. Ülker İnce, İstanbul, Can Yayınları, 2007, s. 145.

12 P.N. Vanezis, Makarios: Pragmatism v. Idealism, London, Abelard-Schuman Limited, 1974, s. 74.

13 Makarios’un gerçek adıdır. Mouskos Başpiskopos seçildikten sonra Makarios III adını almıştır. Ölüm tarihi 3 Ağustos 1977'dir. 
Kıbrıslının yolları 1946'da kesişti. O sıralarda Grivas, Atina siyasetinde tanınmış bir figürdü. St. Irene Kilisesi'nin genç rahibi Michael Mouskos, Zaphyrios Valvis aracılığıyla Grivas'la tanıştı. ${ }^{14}$ Zaphyrios Valvis, Grivas'ın X örgütündeki yardımcısıydı. Tanışma sırasında Grivas 48, Mouskos 33 yaşındaydı. Tanıştıklarında Michael Mouskos, Grivas'ın siyasi partiye dönüştürdüğü X' in yayın organında komünizme karşıtı dini yazılar kaleme alıyordu. ${ }^{15}$ Birkaç ay sonra, Dünya Kiliseler Konseyi tarafindan sunulan on burstan birini aldı ve Eylül ayında Boston Üniversitesi'nde teoloji eğitimi almak üzere Atina'dan ayrıldı. Yaptığ 1 teolojik çalışmalar yanında hitabet dersleri aldı. Boston'da eğitim gördüğü 1948 yılında Kition (Larnaka) Piskoposu olarak seçildi. Michael Mouskos yirmi beş ynaşından otuz beş yaşına kadarki ömrünü çoğunlukla Kıbrıs dışında geçirmiş olmasına rağmen adada karizmatik dini bir hatip olarak biliniyordu. Kition Piskoposu olması Michael Mouskos'u karizmatik bir hatip ve dini liderden daha öteye taşıdı ve onu kendi güç tabanını hızla pekiştiren sağlam bir politikacı yaptı.

Michael Mouskos, halk nezdindeki otoritesini 15 Ocak 1950 tarihinde tertiplediği gayri resmi plebisit ile taçlandırd1. Plebisit her ne kadar gayri resmi olsa da son derece iyi örgütlenmişti. Tüm kiliselerde başlayan oylama 15 Ocak Pazar gününden 22 Ocak Pazar akşamına kadar devam etti. Oylamaya 18 yaşından büyük kadın ve erkekler katılabiliyordu. Oy verme işlemi oldukça basitti. Kişilerden sadece "Enosis istiyoruz" yazılı defteri imzalamaları isteniyordu. Kilise yaptığı açıklamada kullanma hakkına sahip 224.747 kişiden 215.108'in Enosis lehine oy verdiğini ilan etti. ${ }^{16} \mathrm{Bu}$ oyların yüzde 96'sına tekabül ediyordu. İngiliz yönetimi oylamanın yasal olmadığını ve bu nedenle hiçbir sonuç doğurmayacağını ifade ederken, Kıbrıs Türkleri de plebisiti tanımadıklarını ve şiddetle protesto ettiklerini belirttiler. Yine de kilise, oylama sonuçlarını Yunanistan, İngiltere, ABD ile Birleşmiş Milletler üyelerine göndermekten geri durmadı. Michael Mouskos'un 18 Ekim 1950 tarihinde Başpiskopos seçilmesi Enosis mücadelesinde bir dönüm noktasıdır. Büyük bir çoğunluğun desteğini arkasına almayı başaran Mouskos, otuz yedi yaşında artık halkının hem dini hem de etnik lideriydi ve başpiskoposluk gelenekleri doğrultusunda Makarios III' ${ }^{17}$ adını aldı.

Makarios'un liderlik özellikleri ve Enosise olan tutkusu kısa sürede gerek ada sathında gerekse de ada dışında hızla hissedilmeye başladı. Makarios, dört bir koldan yoğun bir Enosis diplomasisini vücuda getirdi. Sadece Yunanistan ve İngiltere ile

14 Charles Foley and W.I. Scobie, The Struggle for Cyprus, Stanford, Hoover Institution Press, 1975, s. 7.

15 General Grivas, Hayatım, ed. Charles Foley, çev. Cumhur Atay, İstanbul, Kalkedon Yayınları, 2012, s. 36.

16 Cypriot National Delegation, The Cyprus Plebiscite and The Greek Parliament, London, 1950.

17 Bundan sonra sadece Makarios ismi kullanılacaktır. 
yetinmeyerek sömürgecilik karşıtı söylemlerin rehberliğinde Asya ve Afrika ülkelerine ulaşmaya çalıştı. $\mathrm{Bu}$ sayede Enosis fikrine uluslararası destek bulmaya çabaladı. Makarios'un başpiskopos olmasıyla kilise, Enosis örgütlenmesine yeni bir ivme kazandırdı. Özellikle sağ örgütleri kendi kontrolü altına almaya çalışırken diğer taraftan yeni örgütler kurmak suretiyle Enosis cephesini genişletme yönünde bir strateji benimsedi.

Makarios Mart 1951'de Atina'ya başpiskopos sıfatıyla üç haftalık bir ziyaret gerçekleştirdi. Öğrencilik ve ilk rahiplik yıllarında burada etkili bir çevreyle tanışma firsatı bulmuştu. Şimdi onlardan özellikle Yunan iç politikasında etkili olan kesimlerden Enosis için yardım istiyordu. Bir taraftan Yunan hükümeti üzerinde baskı kurmaya çalışırken diğer yandan hükümetle ters düşmemek adına azami gayret sarf eden titiz bir çalışma yürütüyordu. Makarios'a göre, Yunan kamuoyu Enosis konusunda heyecanlı ve istekliydi ancak aynı istek ve heyecan hükümette benzer ölçüde bulunmuyordu. İç savaş sonrası bir türlü siyasi istikrarı tesis edemeyen Yunanistan Kıbrıs sorununu Bat1 ittifakı çevresinde, meseleyi uluslararası alana götürmeden İngiltere'yle anlaşarak çözmek niyetindeydi. Diğer taraftan ise kendi kamuoyu önünde Enosis'e sahip çıktığını göstermekten geri durmuyordu. Nitekim Kasım 1951'de Yunan Dışişleri Bakanı Evangelos Averoff, İngiliz Dışişleri Bakanı Anthony Eden'a Enosis karşı1ığında Kıbrıs'takilerin yanı sıra Girit, Kefalonya ve Yunanistan'da 99 yıllığına dört üs teklif etti. ${ }^{18}$ Eden, Yunan mevkidaşına hiç beklemediği bir yanıt verdi: "İngiliz İmparatorluğu satılık değildir ve Kıbrıs sorunu diye bir sorun da yoktur.” ${ }^{19}$ Türkiye'nin 1950'lerin başında Kıbrıs konusunda takip ettiği politika ise adanın siyasi statüsünde herhangi bir değişiklik yapılmaması; şayet bir değişiklik yapılacaksa Türkiye'ye de söz hakkı tanınması gerekliliği üzerine kuruluydu.

Makarios'un mart ayındaki üç haftalık ziyaretinde EOKA konusunda bir dizi görüşme yapmış olma ihtimali yüksektir. Zira 1 Mayıs 1951 tarihinde Kıbrıs Etnark Kurulu üyeleri, sürgünde bulunan Savvas ve Sokrates Loizides kardeşler, Yunanistan'ın eski savaş bakanı Yorgos Stratos ile Grivas Atina'da Tsitsas kafede buluşup, İngilizlere karş1 silahlı bir mücadelenin başlatılması konusunu görüştüler. ${ }^{20}$ Toplantıya katılanlar Grivas'tan bu işe önderlik etmesini istiyorlard. Bu teklifin Etnark Kurulu Başkanı Makarios’tan habersiz yapılma olasıllı̆̆ı oldukça zayıftır.

18 H. D. Purcell, Cyprus, New York, Frederick A. Praeger, 1969, s. 253.

19 H. D. Purcell, Cyprus..., s. 253.

20 Grivas, Hayatım..., s. 32. 


\subsection{George Theodore Grivas}

George Grivas, varlıklı Ortodoks bir Rum ailenin dördüncü çocuğu olarak 23 Mayıs $1898^{21}$ tarihinde Kıbrıs'in Trikomo köyünde dünyaya geldi. Altı kardeştiler ve doktor olan abisi dışında başka erkek kardeşi yoktu. Trikomo köyü verimli tarım arazilerinin bulunduğu denize kıyısı olan bir köydü. Günümüzde Kuzey Kıbrıs Türk Cumhuriyeti sınırları içerisinde kalan bu yerleşim yerinin adı İskele' dir.

Grivas, Yunan milliyetçiliğinin kutsandığı bir çağda yetişti. Çocukluğuna Helenizm, Yunan mitolojisi, Ortodoksluk ve Bizans tarihi yön verdi. Yunan tarihinin destansı olayları, savaşları ve kahramanları onu adeta büyüledi. Çocukluğunun en büyük kahramanı, insanüstü güçlere sahip, savaş tekniğini fevkalade bilen, Bizans İmparatorluğu'nun s1nırlarını Arap saldırılarına karşı başarılı bir şekilde korumuş Dighenis Akritas’tı. Hatta Trikomo köyünün biraz uzağında yer alan büyük bir kaya parçasının Dighenis tarafından firlatıldığına inanan köyün yaşlıları, bu hususta Grivas’ı ikna etmeyi başarmışlardı.

Kıbrıs adası o zamanlar Yunanistan'dan gelen ve gençlere Yunan milliyetçiliğini aşılamayı kutsal bir vazife bilen öğretmenlerle doluydu. Öğretmenler Megali İdea (Büyük Yunanistan düşüncesi) fikrini ilmek ilmek genç beyinlere işlemekten büyük bir keyif al1yordu. 1900'lü yılların başı Megali İdea anlatısı için uygun zamanlardı. 1910 yılında “Girit Kahramanı" ünüyle iktidara gelen Eleftherios Venizelos kısa sürede Yunanistan topraklarını ve nüfusunu ciddi ölçekte artırdı. Bağımsızlığını kazandığ 1 yıldan beri topraklarını sürekli Osmanlı Devleti aleyhine genişleten Yunanistan, Balkan Savaşları (1912-1912) sonrasında Girit, Selanik, Makedonya’nın bir bölümü, Yanya, Sakız, Midilli ve Sisam adalarını kendi ülkesine dâhil etti. Balkan Savaşları sonunda Yunanistan'a katılan yeni topraklar, ülkenin yüzölçümünü yüzde 70 oranında büyütürken, ülkenin nüfusunu da yaklaşık 2.800.000'den 4.800.000'e çıkarttı. ${ }^{22}$ Bu yeni toprak kazanımları Yunanlıları ziyadesiyle onurlandırdığı gibi “kurtarılmamış Yunanlıları” Yunanistan'a katma arzusunu da politik olarak oldukça güçlendirdi. Büyük Yunanistan Krallı̆̆ı'na giden sürecin bir parçası olma isteğini iliklerine kadar hisseden Grivas asker olmaya karar vermişti.

Lefkoşa'daki Pancyprian Lisesi’ni bitirmesinin ardından hırslı bir şekilde 1916 senesinde Atina Askeri Akademisi'nin yolunu tuttu. Böylece Grivas Birinci Dünya Savaşı'nın tüm hızıyla devam ettiği bir ortamda askerlik mesleğine giden yolda en büyük adımı attı. Akademiden mezun olur olmaz soluğu Anadolu'da aldı. Kendisinin ilk görevi Mustafa

21 Grivas 27 Ocak 1974 tarihinde öldü.

22 Richard Clogg, Modern Yunanistan Tarihi, çev. Dilek Şendil, İstanbul, İletişim Yayınları, 1997, s. 107. 
Kemal önderliğindeki "gerillaları" temizlemekti. ${ }^{23}$ Grivas, Yunan milletinin nesillerdir içinde besleyip büyüttüğü "Megali İdea" adı verilen ve Konstantinopolis (İstanbul) başkent olmak üzere, Bizans İmparatorluğu'nu yeniden kurma rüyasına kayıtsız şartsız bağlı bir kişilikti. 1844 yılında Yunanistan'ın resmi dış politikası hüviyeti kazanan Megali İdea, Yunan ve Rum gençlerin de milli ülküsü haline getirilmişti. Megali İdea kabaca şöyleydi:

“Yunanistan Krallı̆̆ , Yunanistan değildir; Yunanistan'ın sadece bir parçası, en küçük, en yoksul bir parçasıdır. Yunanlılar, sadece Krallık içinde oturanlar değildirler, aynı zamanda Yanya'da ya da Selanik'te, Serez'de ya da Edirne'de, Istanbul ya da Trabzon'da, Girit ya da Sisam Adası'nda, Yunan tarihine ya da Yunan ırkına bağlı başka yerlerde oturanlar da Yunanlıdır. Helenizmin iki büyük merkezi vardır. Krallı̆̆ın başkenti Atina'dır. Ístanbul, büyük başkent bütün Yunanlıların kenti, düşü, umududur. ${ }^{24}$ "

Bu teze göre Akdeniz'den Karadeniz'e kadar yayılmış Ortodoks Grekler Yunan ulusunun ayrılmaz bir parçasıydı ve Atina'daki yönetimlerin tüm bu parçaları tek çatı altında birleştirmek gibi tarihi, siyasi ve manevi bir sorumluluğu bulunuyordu. Megali İdea, irredentist pan-helenistik bir ideolojiydi ve hedefinde Klasik Yunan ve Bizans Helenizmine ait bütün topraklar vard $1 .{ }^{25}$ Fark edileceği üzere bu toprakların neredeyse tamamı Osmanlı İmparatorluğu'nun hâkimiyeti altında bulunuyordu. Hemen belirtmek gerekir ki, Osmanlı topraklarında Hıristiyan tebaa tarafindan yürütülen her türlü ayrılık hareketine Avrupalı devletler destek vermekte gecikmiyordu. Söz konusu Yunanlılar olunca bu destek misliyle geliyordu. Zira Modern Avrupa'nın Rönesans döneminden itibaren Helen dünyasına dönük özel bir hayranlığı ortaya çıkmıştı. Bu yüzden Avrupa' daki kamuoyu Yunan davasına coşkulu destek veriyordu. ${ }^{26}$ Açıkça belirtilmelidir ki Atina' daki yönetimlerin Megali İdea'yı gerçekleştirmek konusunda en büyük güvenceleri Avrupa kamuoyundan ve Avrupalı devletlerden gördükleri destekti. Yoksa kendi başlarına bu sınırlara ulaşmalarını sağlayacak ne iktisadi ne askeri ne de siyasi güçleri vardı. Yine de bu destek sayesinde Yunanistan Megali İdea yolundan epey bir mesafe aldı. Ağustos 1922'de Yunan ordusunun yok oluşu ve Başbakan Dimitrios Gounaris'le birlikte beş bakanın idamıla sonuçlanan bir dizi askeri, siyasi, iktisadi ve toplumsal fecaatle yüzleşmek zorunda kaldılar. Böylece 1844 yılında başlayan Megali İdea macerası 1922 yılında resmen çöktü ve Yunanistan'ın Sevr Antlaşması'yla elde ettiği toprak kazanımları Lozan Antlaşması'yla yok olup gitti.

23 Grivas, Hayatım, s. 22.

24 Michael Llewellyn Smith, Yunan Düşü, çev. Halim İnal, Ankara, Ayraç Yayınevi, 2002, s. 17.

25 Vamık D. Volkan ve Norman Itzkowitz, Türkler ve Yunanlılar: Çatışan Komşular, çev. Banu Büyükkal, İstanbul, Bağlam Yayınları, 2002, s. 56.

26 Halil İnalcık, "Helenizm, Megali İdea ve Türkiye”, Doğu Batı: Düşünce Dergisi, S. 31. (Nisan 2005), s. 14. 
Yunanlılar için ağır sonuçları olan bu yenilgi, Grivas'ın da Anadolu macerasını sonlandırdı. Grivas, daha sonra İstanbul'u ele geçirmek için Trakya' da tanzim edilmiş askeri bir bölüğe komutanlık etse de bu, çok kısa ömürlü oldu. Grivas’a göre Türkler savaşı Mustafa Kemal'in zekâsı ve kararlılığı sayesinde kazanmıştı. İlk gerilla savaşını Anadolu'da tecrübe eden Grivas, savaşın hemen ardından 26 yaşında genç bir yüzbaş1 olarak Fransa Piyade Okulu'nun yolunu tuttu. İki savaş arası dönemde Yunan Ordusu'nun çeşitli kademelerinde görevler aldı ve Atina' daki Harp Okulu'nda askeri strateji ve taktik üzerine dersler verdi. ${ }^{27}$

Grivas, Anadolu'nun ardından ikinci gerilla savaşı deneyimini İkinci Dünya Savaşı sırasında Yunanistan'ın İtalyan ve Alman işgaline uğramasıyla Yunanistan'ın kuzeyinde, Arnavutluk sınırında bulunan Pindus dağlarında işgal güçlerine karşı yaşadı. Ekim 1940’te başlayan İtalyan işgalini, Nisan 1941'de Alman istilası takip etmiş ve Yunan hükümeti, Girit adasına kaçmak zorunda kalmıştı. Mayıs ayında Girit'in de Alman istilasına uğramasına üzerine bu defa Kral II. George himayesinde hükümet, İngiltere'nin talimatıyla Kahire'ye sürgüne gitmişti. Dolayısıyla Atina'da resmi bir hükümet bulunmuyordu ve bu başıbozuk ortamda işgal kuvvetlerine karşı halkın oluşturduğu direniş örgütleri mücadele veriyordu. İşgalin sonlarına doğru böyle bir ortamda Atina'ya dönen Grivas güvenilir subaylardan oluşan X adında bir yeraltı örgütü kurdu. Grivas'a göre X örgütü, 300 subay ve çok sayıda sivil görevliyle, Nazi işgaline karşı müttefik kuvvetleri için istihbarat hizmetleri, silah sevkiyatları, sivil halkı örgütleme şeklinde faaliyetler yürütüyordu. ${ }^{28}$ Ancak buna karşın X'in Nazi işgaline karşı bir mücadele yürütmediği, örgütün asıl hedefinin komünistler olduğunu savunan görüşler de bulunmaktadır. ${ }^{29}$ Grivas bu süreçte İngiliz istihbaratıyla yakın bir mesaide bulundu. O, İngiliz yanlısıydı ve işgaller karşısında komünistleri samimi görmüyordu. Ona göre komünistlerin tek bir amacı vardı: İktidarı ele geçirmek. Grivas'ın yazdıklarına bakılırsa X örgütü hem Nazilere hem de komünistlere karşı başarılı bir mücadelenin ardından Şubat 1945 tarihinde lağvedilmişti. Mart 1945 'te ordudan emekli oldu. Grivas, sonrasında örgütünü siyasal partiye dönüştürüp mücadelesine siyaset yoluyla devam etmek istedi. Ancak siyasette umduğunu bulamadı. 1946 yılı ve sonrasında yapılan seçimlerde büyük bir hayal kırıklığına uğradı ve 1951 yılında siyasetten sonsuza dek vazgeçtiğini açıkladı.

27 Grivas, Hayatım, 22.

28 Grivas, Hayatım, 25-27.

29 Roderick Beaton, Greece: Biography of a Modern Nation, Chicago, University of Chicago Press, 2019, s. 315. 


\section{EOKA'nın Kuruluşunu Sağlayan Koşullar ve Yapılar}

1 Mayıs 1951 tarihinde Atina'da yapılan toplantının ardından adada gerilla savaşı olanaklarını yerinde incelemek üzere 23 Haziran'da gerekli resmi işlemleri tamamlamasının ardından eşi Kiki ile birlikte Kıbrıs'a gitti. Grivas üç aylık vize almıştı ve adayı ziyaret sebebini "akraba ziyareti" olarak belirtmişti. ${ }^{30}$ Doktor abisi Michael Lefkoşa'da yaşıyordu ve Grivas eşiyle birlikte burada kaldı. Yirmi yıldan sonra ilk kez adaya gelmişti. Temmuz başından Ağustos başına kadar adada kaldı ve bu süre zarfında adanın sakinlerini, arazi yapısını ve kolluk kuvvetlerinin durumunu titizlikle inceledi. Yetişkin Rumları silahlı mücadele için cesaretsiz ve şevksiz buldu. Ada küçüktü. İngilizlerin etkin bir kontrolü söz konusuydu. O yüzden gerilla savaşı için dinamik bir ruha ihtiyaç vardı. Ayrıca Yunanistan'dan getirilmesi planlanan silah ve mühimmatın çok gizli bir şekilde ada sathına yayılması gerekiyordu. Alman işgali sırasında lise çağındaki Yunan gençlerin gerilla savaşındaki becerilerine şahit olan Grivas, ancak benzer bir örgütlenmeyle adada İngilizlere karşı durabileceklerine kanaat getirdi. Adaya gelişinden hemen sonra ve adadan ayrılmadan hemen önce, toplamda iki defa Makarios'la görüştü. Bu görüşmeler 1 Mayıs 1951 tarihinde Tsitsas kafede yapılan toplantıdan Makarios'un haberdar olduğunu işaret etmektedir. Temmuz-Ağustos 1951 tarihli Makarios-Grivas buluşmalarında silahlı mücadelenin şekli, gençlerin rolü, parasal yardımlar, silah sevkiyatı ve örgütün yapısı konularının ele alındığı, daha sonraki gelişmelerden anlaşılmaktadır.

Kıbrıs Kilisesi'nin gücü ve etkisi, Kilise'nin adadaki Enosis hareketini şekillendirmedeki rolü zaten biliniyordu. 1931 İsyanı sonrasında Kilise'nin siyasi yaşamdaki etkisi büyük ölçüde azaltılmıştı. 1947 yılında Başpiskoposluk seçimleri yeniden yapılana kadar Kilise'nin oluşturduğu siyasi boşluğu sol örgütler, kuruluşundan sonra da AKEL doldurmuş̧tu. Fakat Makarios ile birlikte Kilise yeniden eski haşmetli gücünü tazeledi ve Kıbrıs Rum siyaseti üzerinde tam bir hâkimiyet tesis etti. Öyle ki Kilise kısa süre içerisinde milliyetçi ve sağcı örgütleri birbirine bağlayan doğal bir kanal ve milliyetçi kampı kendi çatısı altında birleştiren bir güç haline geldi. Bu dönemde Kilise artık hem dini hem de milliyetçi üst bir kurumdu ve Başpiskopos da onun doğal önderiydi. Ayrıca bu bütünleşmiş kimlikte komünistlere yer yoktu. Makarios, her ne kadar gayri yasal olsa da, 1950 Plebisiti'nde halkın Enosis iradesini yazılı olarak teyit etmişti. Organizasyonun Kilise, oylamanın ise kiliselerde yapılması Enosis davasında siyasi önderin adresini açıkça ortaya koymuştu. Makarios Enosis kampanyasının politik ve dini lideri sıfatıyla Enosis taahhüdünü yerine getirmek üzere kendisine geniş ve dokunulmaz bir alan

30 The National Archives, KV 2/3883: Gorgios GRIVAS: Greek. Leader of the military campaign in Cyprus for Enosis. 
açtığına göre şimdi attığı her adımın Enosis için olduğunu Rum halkına kolayca anlatabilir ve onlardan her türlü desteği talep edebilirdi. Bu bağlamda Kilise'nin siyasi rolünü kitleler üzerinde artırmak amacıyla din adamları köylerde, öğretmenler okullarda, gazeteler topluma, birlikler de üyelerine yukarıdan aşağıya doğru Enosisi vaaz ettiler ve cemaatleri üzerindeki Enosis baskısını korudular. Kilise teşkilatının ada sathında yeniden tüm yönleriyle güçlendirilmesi, EOKA’nın kurulmasına büyük bir cesaret verdi. EOKA'nın maddi finansmanında, örgüt üyelerinin barınması, beslenmesi ve yeri geldiğinde saklanmasında Kilise kurumu kayda değer bir vazife üstlendi. Örneğin Makarios'un ilk gençlik yıllarının geçtiği Cikko (Kykkou) Manastırı, EOKA'nın ana finansörlerden biriydi ve hem manastırın içinde hem de çevresinde gerillalara güvenli bir barınak imkânı sunuyordu. Bu nedenle İngilizler, manastırı Haziran 1956'dan Mart 1959'a kadar halka kapatmak zorunda kald1.

Makarios aynı zamanda Kilise'nin doğrudan kendi kitlesel dayanaklarını oluşturmak amacıyla da çalıştı. Bu çerçevede kendine bağlı yeni gençlik örgütleri kurmayı ihmal etmezken diğer taraftan kendisine bağlı olanları da yeniden örgütledi. PEON ${ }^{31}$ gençlik örgütü bu düşünceyle Ocak 1951'de Makarios tarafindan kuruldu. ${ }^{32}$ Makarios'un amac1, Enosis hareketlerini tek çatı altında koordine ve kontrol etmek amacıyla milliyetçi gençlik örgütlerini Kilise'nin mutlak denetimi altına almaktı. PEON tamamen Kilise'nin himayesi altındaydı. Tüzüğünde herhangi bir değişiklik yapabilmesi Başpiskoposun onayına bağlıydı. Yine PEON yöneticilerini atama görevi Kilise'ye aitti. PEON üyeleri 18-40 yaşlarında, milli değerlere ve ideallere bağlı kişiler arasında seçiliyordu. Örgütün genç milliyetçi üyeleri Kilise'nin vereceği talimatlar yanında, propaganda, gösteri, boykot ve hatta sabotaj eylemlerini yürütmekten sorumluydu. ${ }^{33}$ PEON'un ilk Genel Sekreteri, Stavros Poskotis idi. PEON, Haziran 1953 tarihinde yürüttüğü yasadışı eylemlerden dolayı İngiliz yönetimince kapatıldı. Üyelerinin birçoğu OHEN'e kaydırıldı. ${ }^{34}$

Bir diğer önemli gençlik teşkilatı 1939 yılında kurulan OHEN ${ }^{35}$ adlı örgüttü. Bu örgüt Kilise'nin önemli bir aracıydı. OHEN komünizme ve dindar olmayan örgütlere karş1 kurulmuştu. PEON gibi Kilise’nin himayesindeydi. Örgüt 1950 plebisitinde kişilerin oylamaya katılım sağlaması için öncü bir rol üstlenerek varlığını hissettirmişti. Tahmin

31 Pancyprian National Youth Organisation: Kıbrıs Birliği Ulusal Gençlik Teşkilatı.

32 Yiannos Katsourides, The Greek Cypriot Nationalist Right in the Era of British Colonialism, Switzerland, Springer International Publishing, 2017, s. 205.

33 Yiannos Katsourides, The Greek Cypriot, s. 205.

34 David French, Fighting EOKA: The British Counter-Insurgency Campaign on Cyprus 1955-1959, New York, Oxford University Press, 2015, s. 40.

Orthodoxos Christianiki Enosis Neon: Yunan Ortodoks Gençlik Birliği. 
edileceği üzere üyelerinin büyük çoğunluğu Enosisin fanatik destekçileriydi. OHEN üyeleri Enosis kampanyasının ayrılmaz bir parçasıydı. Her ne kadar İkinci Dünya Savaşı sonrası sol örgütlerin ve diğer milliyetçi örgütlerin kurulmasıyla OHEN'e yönelik ilgi düşüşe geçmiş olsa da Makarios teşkilatın yeniden büyümesi için tüm imkânlarını seferber etti. 1955 yılına gelindiğinde OHEN'in toplamda yaklaşık 3000 üyesi bulunuyordu. ${ }^{36}$ Başpiskopos ya da Piskoposlar tarafından kontrol edilen OHEN üyeleri aynı zamanda diğer milliyetçi örgütlerle iş birliği içerisinde bulunuyorlardı. OHEN'in en önemli tarafi, köylerde etkin olmasından ileri geliyordu. Üye yelpazesi PEON'a nazaran daha genişti. Örgüt 12 yaşından itibaren gençlerle irtibata geçiyor ve 16 yaşından sonra da onları üyeliğe alıyordu.

Makarios ve Grivas tarafından PEON ve OHEN teşkilatlarının üyeleri EOKA'nın arka bahçelerine dönüştürüldü. Bu iki örgüt şehirlerde lise öğrencilerinin propaganda, gösteri ve boykot eylemlerinde bulunmalarında aktif bir rol üstlendi. Dahası EOKA'ya militan tedariki, kurye hizmetleri, ajanlık, sabotaj eylemleri, silah sevkiyatları gibi birçok faaliyet bu örgütlerin üyeleri üzerinde gerçekleşti. Dolayısıyla EOKA'nın bu iki gençlik teşkilatı üzerine kurulduğunu söylemek herhalde abartı sayılmaz.

EOKA'nın ada sathında örgütlenmesine yardım eden bir diğer önemli kuruluş Çiftçiler Birliği (PEK) idi. PEK, 1942 yılında kurulmuştu. Adanın en çok üyesi olan kurumlarından biriydi ve gerek yöneticilerinin gerekse de üyelerinin çoğu Enosis taraftarıydı. Aynı zamanda komünizm karşıtıydı. Kilise ile yakın bağları vardı. Öyle ki Genel Sekreteri Savvas Loizides, Enosis referandumuyla ilgili eylemlerinden ötürü Şubat 1950’de sınır dışı edilmişti. Adanın temel geçim kaynağının tarım olması ve toplumun büyük çoğunluğunun köylerde yaşaması nedeniyle PEK'in köy örgütlenmesi kuvvetliydi. 1949 yılında ada genelinde yaklaşık 10 bin üyesinin olduğu tahmin ediliyordu. Bu yüzden PEK, EOKA'nın kırsaldaki en önemli ayağını oluşturuyordu. 1954 yılında PEK'in Genel Sekreter koltuğuna oturan Andreas Azinas Makarios'un önemli adamlarından biriydi ve Grivas ile iletişim onun üzerinden sağlanıyordu. Azinas, aynı zamanda adaya silah sokulmasında, silahların gizlenmesinde ve dağıtılmasında paha biçilmez bir görev üstlendi. Azinas, Yunanistan'dan gönderilecek silahlar için en uygun ve güvenilir yer olarak Baf kıyısındaki Hloraka köyünü Grivas'a tavsiye etti ve beraber köyü ziyaret ettikten sonra burası için karar verdiler.

Kıbrıs'a ilk ziyaretinin ardından Grivas, 10 Ağustos 1951'de Atina'ya geri döndü. Atina'da kendisine maddi ve manevi destek sağlayabilecek kişilerle irtibata geçmeye

36 Yiannos Katsourides, The Greek Cypriot, s. 204. 
çalıştı. Muhalefet lideri General Papagos'tan pasif destek sağladı. 2 Temmuz'da Başpiskopos Makarios başkanlığında eski savaş bakanı Yorgos Stratos, Grivas, Savvas ve Sokrates Loizides kardeşler, General Papadopulos (Kıbrısl1), X'in eski bir mensubu Albay Elias Alexopulos, Atina Üniversitesi'nden Profesör Yerasimos Konidaris ile Profesör Demetrios Vezanis ve bir de Avukat Antonios Avgikos olmak üzere toplam 10 kişi bir toplantı yaptılar. ${ }^{37}$ Toplantıda, Kıbrıs için gizli bir Kurtuluş Komitesi kurulmasına karar verildi. Böylece 1 Mayıs 1951'de kurulması planlanan örgüt bu toplantıya ete kemiğe büründürüldü. Hem bu toplantıda hem de devamı niteliğindeki 21 Temmuz tarihli toplantıda temel tartışma konusu silahlı mücadelenin hangi yöntemle verileceğiydi. Grivas, kırsalda gerilla tekniği şehirlerde de sabotajlar yoluyla iki koldan saldırılar yapılmasını öneriyordu. Makarios gerilla savaşına ısrarla direniyordu. Ona göre gerilla savaşına gerek yoktu. Sabotajlar yeterliydi. ${ }^{38}$ Başpiskopos birkaç ay devam edecek sabotaj eylemleriyle İngilizlerin yola geleceğini umuyordu. Makarios ayrıca bu süreçte Yunanistan'dan kimsenin gelmemesi gerektiğini sıkı sıkıya tembihliyordu. Amacı, eylemlerin ardında yalnızca Kıbrıslı Rumların olduğunu dünya kamuoyuna göstermekti.

Tartı̧̧ma henüz kesinliğe kavuşmadan Grivas daha detaylı bir inceleme yapmak ve örgütün mücadelesinin ilk hazırlıklarını yapmak üzere yalnız başına 5 Ekim 1952 tarihinde Kıbrıs'a gitti. ${ }^{39} \mathrm{Bu}$ ziyaretini daha uzun süreli planlamıştı. Yaklaşı beş ayını burada geçirdikten sonra adadan 25 Şubat 1953 'te ayrlacaktı. ${ }^{40}$ Gelir gelmez Beşparmak ve Trodos dağlarını ziyaret etti ve buraların gerilla savaşına müsait olup olmadıklarını inceledi. Kasım ayında ise yukarıda bahsi geçtiği üzere Anazis ile birlikte Hloraka köyünü silah sevkiyatı bakımından irdeledi. PEON ve OHEN liderleri Poskotis ve Pastavros ile görüştü ve onlardan silah sevkiyatında kullanılacak güvenilir gençleri seçmelerini talep etti. Grivas bu beş aylık saha araştırması süresince gerekli tüm saldırı planlarını hazırladı. Grivas, adadaki arazi koşullarının uzun soluklu bir gerilla mücadelesi için yeterli olmad1ğ1 kanaatiyle, esas ağırlığ sabotajlara verilmesini uygun gördü. Yine gerilla savaşından tam olarak vazgeçmiş değildi. O tüm hazırlıklarını her iki saldırıya göre yapmaya devam edecekti. Sabotaj eylemlerinin istenilen sonucu verebilmesini kolluk güçlerinin ilgisini başka yöne çekecek çatışma gruplarının varlığına bağlıyordu. O yüzden sabotajı tek başına yeterli görmüyordu. Planı üç aşamalıydı: Hükümet tesislerine ve askeri noktalara karş1 sabotajlar, İngiliz kuvvetlerine çok sayıda silahlı çatışma gruplarıyla saldırılar ve

37 Grivas, Hayatım, 37.

38 P. N. Vanezis, Makarios, s. 79.

39 KV-2-3883_007.

40 KV-2-3883_010. 
halkın pasif direnişinin örgütlenmesi ${ }^{41}$ Grivas'ın tüm bunları hayata geçirmekteki amacı İngiliz kuvvetlerini tam bir maddi yenilgiye uğratarak adadan göndermek değildi. Esas gaye onları sürekli taciz altında tutarak manevi açıdan yıpratmak ve nihayetinde pes etmelerini sağlamaktı. Bu hedef ışığında büyük şehirlerde eş zamanlı olarak polis karakollarına, radyo istasyonlarına, elektrik santrallerine, askeri kışlalara, mahkemelere, yollara, köprülere, kamu mallarına ve hükümet binalarına bombalı saldırılar yapılacaktı. Silahlı saldırıların yanı sıra sivillerin gücünden de istifade etmeyi planlıyordu. Bu noktada PEON ve OHEN başta olmak üzere adadaki milliyetçi tüm teşkilatlar sahaya sürülerek, İngilizlerin ve onlara destek veren firmaların boykot edilmesi teşvik edilecek ve sömürge yönetiminin baskıcı önlemlerine karşı protesto gösterileri tertiplenecekti. Böylece uluslararası kamuoyunun dikkati hızlı bir biçimde adaya yönelecekti.

İletişim ve ulaşım kanallarının İngilizlerin kontrolünde olduğu küçük bir adada, örgüt üyelerinin yakalanmadan işlerini yürütebilmeleri için halk desteği zaten elzemdi. Ayrıca silah mücadele kadar Rum halkının topyekûn bir şekilde İngilizlere başkaldırısı önem arz ediyordu. EOKA'ya destek vermeyenleri açık bir biçimde cezalandırmak ve böylelikle topluma korku vermek ellerindeki en büyük silahtı. Bu bağlamda, örgüt üyelerini if̧̧a edenler, onları barındırmaktan ya da gizlemekten kaçınanlar, asker, polis veya hükümet ajanlarıyla iş birliği yapanların infaz edileceği EOKA'nın dağıttığı bildirilerde yer alıyordu. İşin bir de Kilise boyutu vardı. Makarios bir vaazında şöyle demişti: "Hükümetin anayasal baskısına boyun eğebilecekleri ulusal davamızın düsşmanı olarak değerlendireceğiz. Bu kişileri hain gibi markalayacağız ve onları halkın öfkesinden ve ayıplamasından korumayacağız."² Görüldüğü üzere Rum halkına yönelik çift yönlü bir bask1 söz konusuydu.

Teorik ve saha planlamalarını tamamlamasının ve onların bir kopyasını Makarios'a bırakmasından sonra Grivas, Şubat 1953'te Kıbrıs'tan ayrıldı. Atina'daki en büyük vazifesi gerekli silahları temin etmek ve onları adaya sevke hazır hale getirmekti. Makarios'tan nakdi yardım gelene kadar X örgütüne ait saklı silahlar ile iç savaş yıllarından kalma silahları toplamaya başladı. 7 Mart 1953 tarihinde Makarios başkanlığında Kurtuluş Komitesi Atina'da bir toplantıda bir araya geldi. Komitenin on iki üyesi de toplantıda hazır bulunuyordu. Komite üyeleri toplantı sırasında gizlilik ve sadakat yemini etti: "Kutsal Teslis adına Enosis davasıyla ilgili bütün bildiklerimi ve bileceklerimi işkence altında ya da hayatım pahasına bile olsa gizli tutacağıma yemin ederim. Bana verilen talimatlara her zaman sorgusuz uyacağım." ${ }^{43}$

41 Grivas, Hayatım, s. 258 (Ek I).

42 P. N. Vanezis, Makarios, s. 75.

43 Grivas, Hayatım, s. 41. 
1952 y1lında Yunanistan'da siyasi hayat istikrara doğru emin adımlarla ilerliyordu. Yunan İç Savaşı'nın muzaffer komutanı Genaral Papagos, 19 Kasım 1952’deki seçimleri büyük bir oy farkıyla kazanmış ve güçlü bir hükümet kurma şansı elde etmişti. Başbakan Papagos, İngiltere'nin desteği sayesinde iç savaşı kazanmış birisi olarak bu ülkeyle çatışmaktan uzak durmaya gayret ediyordu. Fakat diğer taraftan Makarios ile birlikte Enosis rüzgârı Atina sokaklarında daha sert esiyordu ve bu duruma kayıtsız kalmak olası değildi. Bu kaygılara rağmen Yunan parti liderleri içinde Enosis hassasiyeti en yüksek olan ve iktidara geldiğinde konuyu Birleşmiş Milletlere götüreceğine söz veren tek lider Papagos'tu. ${ }^{44}$ O başlangıçta İngiltere'yle doğrudan görüşmeler yoluyla bu meseleyi çözebileceğini umuyordu. Yine de Papagos hükümeti Enosis iddialarında Kilise ve milliyetçileri aktif olarak desteklemekten geri durmuyordu. ${ }^{45}$ Makarios'un ise 1952 'den itibaren yurtdışı görüşmelerini hızlandırdığı görülüyor. Bu kapsamda Mısır, Suriye ve Lübnan’ı ziyaret etmiş ve sonrasında da ABD, Fransa ve Almanya'ya gitmişti. Diğer taraftan da sorunu vakit kaybetmeden Birleşmiş Milletlere götürmesi için Papagos'a baskı yapıyordu.

10 Mart 1953'te Grivas, Makarios ve Savvas Loizides, Grivas'1n Atina' daki dairesinde bir araya geldiler. ${ }^{46}$ Gündem Grivas'1n Kıbrıs ziyaretiydi. Grivas, sabotaj ve gerilla savaşı için gerekli planların hazırlandığı ve bu planların uygulanmasında 1srarcı olduğunu yineledi. Makarios gerilla fikrine zaten karşı olduğunu daha önceki toplantılarda ifade etmişti. Başpiskopos adada İngilizleri Enosise razı etmek için kuvvet kullanılması fikrine katıldığını lakin gerilla savaşını uygun görmediğini bir kez daha teyit ediyordu. Komitenin Makarios dışındaki üyeleri Grivas'la hemfikirdi. Yine de bu hususta bir karara varamadan dağıldılar. Başbakan Papagos Enosis taraftarıydı. Diplomasi marifetiyle bu işin üstesinden gelmeyi tasarlıyordu. Makarios önderliğinde kurulan ve Kıbrıs’ta silahlı saldırılan planları hazırlayan Kurtuluş Komitesi'nden haberdardı. Sadece isminin bu olaylar içerisinde geçmesini siyaseten doğru bulmadığından Grivas’ı bu hususta ağzını sıkı tutması için tembihlemişti. ${ }^{47}$ Belki ki Enosis konusunda diplomatik girişimler tükendiğinde adada tetiğe basılacaktı. Tüm hazırlıklar buna işaret ediyordu.

Yapılan hazırlıklardan bilgisi olan Yunan Dışişleri Bakanı Stefanos Stefanopulos, Komiteyi kendilerinden habersiz herhangi bir eyleme girişmemesi için uyardı. Bunun nedeni Yunan hükümetinin bu tarihlerde iki yönlü bir diplomasi yürütme kararı almasından ileri geliyordu. Öncelikle İngiltere ile müzakere yolu sonuna kadar denenecek şayet

44 Şükrü S. Gürel, Kıbrls Tarihi, s. 89.

45 Yiannos Katsourides, The Greek Cypriot, s. 208.

46 Grivas, Hayatım, s. 41.

47 Grivas, Hayatım, s. 41. 
buradan olumlu bir netice elde edilemezse mesele Birleşmiş Milletlere götürülecekti. Eğer Birleşmiş Milletlerden de müspet bir sonuç alınamazsa o zaman silaha başvurulacaktı. O yüzden Atina-Kıbrıs hattında her üç stratejiye uygun çalışmalar ilerletiliyordu. Bu bağlamda 23 Haziran 1953 tarihinde Makarios adada sabotaj hazırlıkları için gerekli askeri malzemenin satın alınması amacıyla ilk parayı gönderdi. Böylece adada terör eylemleri için ilk adım atıldı. Bir taraftan terör eylemleri adına hazırlıklar sürerken diğer taraftan diplomatik çalışmalar yürütülüyordu.

Papagos Enosis için diplomasi ringine ilk kez Eylül 1953’te çıktı. İngiliz Dışişleri Bakanı Anthony Eden Amerika'da geçirdiği akciğer ameliyatından sonra hava değişimi ve biraz da dinlenmek üzere Yunanistan'da bulunuyordu. Papagos Eden'a 22 Eylül 1953 'te bir nezaket ziyareti gerçekleştirdi. Görüşmede genel mevzuların konuşulduğu bir sırada konu Kıbrıs'a geldi. Papapos, Kıbrıs'ın geleceği hakkında İngiltere'nin ne düşündüğünü sordu. Eden, Kıbrıs meselesinin İngiltere için kapalı olduğunu ifade ettikten sonra, "Yunan hükümetlerinin neden Kıbrıs'tan daha fazla Rum nüfusa sahip olan New York ya da İskenderiye için Enosis istemediklerini sordu." ${ }^{48} \mathrm{Bu}$, Papagos'un beklediği bir cevap değildi. Eden'ın bu sert cevabı karşısında sohbet daha fazla sürdürmedi ve Papagos görüşmeden ayrıldı. İleride ortaya çıkan gelişmeler dikkate alındığında bu gayri resmi görüşmenin geleneksel dostane İngiliz-Yunan ilişkilerine ağır bir hasar verdiği ve ilişkilerde bir kırılma meydana getirdiği anlaşllıyor. Bu tarihlerde Enosis faaliyetlerinin hızlanmasını sağlayan faktörlerden birisi de İngiltere'nin 1950'lerin başından itibaren Kıbrıs'1 İngiltere'nin Ortadoğu Komutanlığı üssü olarak belirlemesi ve bu minvalde hazırlıklara başlamış olmasıydı. ${ }^{49}$ Söz konusu endişenin 29 Ocak 1954 tarihinde Atina'da toplanan Kurtuluş Komitesinin kararlarına yansıdığı görülür. Nitekim toplantıda Kıbrıs'ın Büyük Britanya'nın askeri üssü haline getirilmeden adada planlanan silahlı eylemlerin yapılmasına karar verildi. ${ }^{50}$ Kararın ardından daha önce temin edilen silah ve mühimmatların sevkiyat işlemleri için harekete geçildi. Silah sevkiyatından Çiftçiler Birliği Genel Sekreteri Andreas Azinas sorumluydu. Azinas şubat sonunda Kıbrıs'tan Atina'ya geldi. Grivas'tan aldığı direktifler çerçevesinde silahları güvenli bir şekilde Hloraka'ya ulaştırmak amacıyla ilk silah sevkiyatını 2 Mart gecesi Attika'nın 1ssız bir sahilinden başlattı. ${ }^{51}$

Silah sevkiyatının başlamasından on üç gün sonra, Dışişleri Bakanı Eden Avam Kamarasında yaptığı konuşmada İngiliz hükümetinin Kıbrıs'ın statüsünü tartışmak

48 Robert Holland, Britain and the Revolt in Cyprus 1954-1959, New York, Oxford University Press, 1998, s. 32.

49 "Kıbrısta askeri üs kuruluyor", Milliyet Gazetesi, 20 Mart 1954.

50 Grivas, Hayatım, s. 42.

51 Grivas, Hayatım, s. 43. 
niyetinde olmadığını ve bu durumun Yunan hükümetine açıkça bildirildiğini açıkladı. ${ }^{52}$ Dışişleri Bakanı'nın 15 Mart 1954 tarihli konuşmasına Yunan kamuoyu oldukça sert bir tepki verdi. Basın İngiltere'ye adeta zehir kusarken, Atina ve Selanik'te İngiltere'yi protesto eden öğrenci gösterileri tertipleniyordu. Rodos’ta ise taşkınlık yerini şiddete bıraktı ve göstericiler buradaki İngiliz Konsolosluğunu taşlayarak, binanın camlarını kırdılar. ${ }^{53}$ Makarios'un Atina ve Rodos'ta bulunduğu sırada olayların patlak vermesi dikkat çekiciydi. İngiltere'nin Atina Büyükelçisi Sir Charles Peake olayları şiddetle protesto ederken, Papagos, "Kıbrıs meselesi bulanık bir hava içinde İngiliz-Yunan dostluğuna zarar veren hareketlerle halledilemez"54 açıklamasıyla kamuoyunu ve İngiltere'yi teskin etmeye çalışıyordu. Yunanistan soruna daha fazla sahip çıktıkça meseleyi şiddet dolu bir mecraya hızla sürüklüyordu.

İngiltere'nin Yunanistan'ın ısrarına rağmen Kıbrıs meselesini gündemine almaması üzerine 15 Nisan 1954 tarihinde Papagos hükümeti Kıbrıs sorununu Birleşmiş Milletler Genel Kuruluna götürme kararı aldı. Başbakan Papagos ve Dışişleri Bakanı Stefanopulos bu kararın alınmasından sonra Grivas'1, Birleşmiş Milletler görüşmelerinden önce Kıbrıs'ta Yunan diplomasini zora sokacak herhangi bir eylemin yapılmaması yönünde bir kez daha uyardılar. Birleşmiş Milletlerden çıkacak kararın sonucu beklenecekti. 27 Temmuz 1954 tarihinde Enosis taraftarlarının bekledikleri endişe gerçekleşti. Başbakan Winston Churchill idaresindeki muhafazakâr hükümet, Mısır topraklarındaki İngiliz askeri gücünün tamamını 20 ay içerisinde geri çekmeyi taahhüt eden bir antlaşmayı Mısır hükümeti ile imzalamak zorunda kaldı. Antlaşmayla birlikte Kıbrıs'ın Ortadoğu Komutanlığının yeni merkezi olma konusu da kesinleşti. Antlaşmanın imzalanmasından bir gün sonra, yani 28 Temmuz 1954’te, İngiliz Koloniler Bakan Yardımcısı Henry Hopkinson, Avam Kamarasında yaptığı bir konuşmada Kıbrıs'ın hiçbir zaman tam anlamıyla bağımsız olamayacağını belirten bir ifade kullandı. Hopkinson'un bu ifadesi Sömürgeler Bakanı Oliver Lyttleton tarafindan da desteklendi. 1954 Temmuz'unda meydana gelen bu iki gelişme Kıbrıs'a dair İngiliz tutumunun kısa süre içerisinde değişmeyeceğini gösteriyordu.

Temmuz ayının sonlarına doğru bazı şüphelerin açıklığa kavuşmasıyla Kurtuluş Komitesinin faaliyetlerinin hızlandığı ve bu çerçevede ağustos ayının başında Makarios'un ikinci silah sevkiyatının yapılması için gerekli parayı gönderdiği görülmektedir. Diğer taraftan Yunan hükümeti, “eşit haklar ve self-determinasyon ilkelerinin, Birleşmiş Milletler koruyuculuğu altında, Kıbrıs adasında yaşayan nüfusa

52 “İngiltere, Kıbrıs hakkında Yunan teklifini reddetti”, Milliyet Gazetesi, 16 Mart 1954.

53 "Rodosta İngiliz elçilik binası taşa tutuldu”, Milliyet Gazetesi, 20 Mart 1954.

54 Milliyet Gazetesi, 20 Mart 1954. 
uygulanması" talebiyle 16 Ağustos 1954 tarihinde Birleşmiş Milletlere resmi başvurusunu gerçekleştirdi. ${ }^{55}$ Böylelikle Kıbrıs meselesini uluslararası bir sorun haline getirilecek adım Yunanistan tarafından atılmış oldu. Atina'nın bir yüzünde Enosis için diplomasi en üst seviyeye çıartılırken öteki yüzünde adada terör eylemlerinin hazırlıkları devam ediyordu. 24 Eylül 1954'te Birleşmiş Milletler, Kıbrıs maddesini gündemine almaya karar verdi fakat meseleyi inceleyip bir karar vermeyi ileri bir tarihe erteledi.

Ekim ayında müzakerelerin yeniden başlayacağını haber alan Makarios propaganda faaliyetleri yürütmek adına New York'a gitmek için Atina'ya geldi. Bu sırada Grivas'a silah sevkiyatını hızlandırmasını ve vakit kaybetmeden kendisinin adaya gitmesini söyledi. Makarios bu kararı, Yunan Dışişleri Bakanı Stefanopulos ile birlikte almıştı. Niyetleri Kıbrıs görüşmeleri öncesi ilk eylemin gerçekleştirilmesiydi. New York’taki Yunan delegesinden gelen malumatlara göre Atina'daki fikir sürekli değişiyordu. Makarios Grivas'a saldırının ne zaman olacağına dair haberi Amerika'dan bildireceğini iletti. Fakat bu karar da hemen değiştirildi. Yapılan son toplantıda Grivas'a adaya varır varmaz saldırıyı yapmasını söylediler. ${ }^{56} 26$ Ekim 1954 tarihinde Grivas gizlice Kıbrıs'a gitmek üzere parası Makarios tarafından ödenmiş bir tekneyle Pire'den hareket ettiler. Yanında komitenin üyelerinden ve Kıbrıs'tan sürgün cezası almış Sokrates Loizides vardı. Önce Rodos'a uğradılar. Hava şartlarının olumsuz seyretmesinden dolayı Rodos'tan ancak 8 Kasım akşamı yola çıkabildiler.

İki günlük yolculuğun sonunda Hloraka'ya vardılar. Ertesi gün vakit kaybetmeden bir taraftan Hloraka köyünde saklı tutulan silahları beş büyük kentteki örgüt mensuplarına teslimi ile PEON ve OHEN'den seçilmiş militanların eğitimi işine koyuldular. Kasım sonunda militanların eğitimleri, aralık sonunda da silahların sevkiyatı tamamlandı. $\mathrm{Bu}$ işlemler sürerken Birleşmiş Milletler 15 Aralık’ta Yunanistan'ın başvurusunu reddeden kararı alıyordu. Kararın adaya ulaşmasıyla birlikte 14 polisle 22 göstericinin yaralandığı, 48 kişinin tutuklandığı ciddi gösteriler baş gösterdi. Gösteriler üzerine bir radyo konuşmasıyla halkı uyaran Kıbrıs Valisi Sir Armitage, adada asayişi ve düzeni bozmaya yeltenenlerin cezalandırılacağını ifade etmesinin yanında aileleri de çocuklarını bu tür gösterilerden uzak tutmaları için uyard1 ${ }^{57}$ Enosisçilere göre artık diplomasinin sonuna gelinmişti. Bundan sonra tek seçenek terör eylemleri yoluyla İngilizleri yola getirmekti.

55 Stephen G. Xydis, “The UN General Assembly as an Instrument of Greek Policy: Cyprus, 1954-58”, The Journal of Conflict Resolution, Vol. 12, No. 2 (Jun., 1968), s. 141.

56 Grivas, Hayatım, s. 45.

57 “Kıbrıs’ta fevkalâde hâl ilân ediliyor”, Milliyet Gazetesi, 20 Aralık 1954. 
EOKA gizli bir yeraltı örgütü olarak tasarlandı ve adanın beş büyük kentinde gizli şubeler açtı. Her şubenin başında bir lider vardı ve liderlerin en temel vazifesi örgütlenmeyi köylere kadar büyük bir gizlilik içerisinde yaymaktı. Üyelerin güvenilir, yetenekli ve milliyetçi kişilerden seçilmesine özen gösteriliyordu. Örgüt, komünistlerden üye kabul etmiyordu. Hücre tipi örgütlenme esastı ve bu kapsamda bir üyenin başka bir üyeyi tanımamasına azami dikkat ediliyordu. Örgüt, PEON ve OHEN üyeleri üzerinden iyi bir istihbarat ve kurye ağı kurdu. Zaten EOKA'nın militan kadrosunu ağırlıklı olarak bu gençler oluşturuyordu. Grivas, PEON ve OHEN vasıtasıyla okul sınıflarına kadar temsilciler görevlendirdi. Sınıf temsilcilerinin görevi, kız ve erkek ayrımı yapmadan güvenilir öğrencilerden üyeler seçmek ve EOKA'dan gelen emirleri büyük bir itaat içerisinde uygulamaktı. Öğrencilerin büyük çoğunluğu EOKA lehine yapılan kitlesel gösterilerde yer alırken bazıları ajanlık, ulaklık, duvar yazıları yazmak ve broşür dağıtmak gibi görevler üstlendiler. EOKA'nın hedefinde sadece öğrenciler yoktu. Okul çağındaki çalışan gençler de örgütün üye havuzundaydı. Örgüt üyelerinin aşağıdaki yemini etmeleri zorunluydu:

"Kutsal Teslis adına yemin ederim ki, Kıbrıs'ın İngiliz boyunduruğundan kurtarılması için hayatımı bile feda edecek şekilde bütün gücümle çalışacağım. Örgütün bana verebileceği bütün talimatları sorgusuz yerine getireceğim ve bunlar ne kadar zor ve tehlikeli de olsa hiçbir itirazda bulunmayacağım. Örgütün liderinden talimat almadıkça ve amacımı başarılmadıkça mücadeleyi terk etmeyeceğim. Yakalanıp işkence edilsem bile ne örgütün bir sırrını ne de şeflerimin ya da diğer üyelerin isimlerini asla kimseye açıklamayacağım. Bana verilen bir talimatı savaşçı arkadaşlarıma bile açıklamayacağım. Bu yemine uymazsam, hain olarak her cezaya lâyı̆̆ım ve ebedi yüzkarasına bürüneyim. ${ }^{58}$ ",

10 Ocak 1955'te Makarios adaya döndü ve ertesi gün Grivas ile buluştular. ${ }^{59}$ Görüşmede Makarios, Papagos'un eylemlere tam destek verdiğini söyledi. Toplantıda örgüte Grivas'ın isim babası olduğu EOKA adı verildi. ${ }^{60}$ Kendisine de çocukluğundan beri hayranlık duyduğu Bizans'ın mitolojik halk kahramanı Dighenis'i kod adı olarak alıyordu. Toplantıda ilk saldırının ne zaman yapılacağı da ele alındı. Makarios 25 Mart'ta yapılmasını teklif ederken, Grivas bu tarihi oldukça geç buluyordu. ${ }^{61}$ Ona göre saldırı en kısa zamanda yapılmalıydı. Ancak Ocak ayı sonunda beklenmedik bir durumla karşılaştılar. 13 Ocak'ta Yunanistan'dan yola çıkan 27 sandık silah ve patlayıcı yüklü St. George teknesi 26 Ocak günü Hloraka sahilinde İngilizler tarafından ele geçirildi. Bu olay üzerine İngiltere ve Türkiye, Yunanistan'a nota verirken, basın Kıbrıs’ta gizli

58 Grivas, Hayatım, s. 46-47.

59 Grivas, Hayatım, s. 50.

60 Grivas, Hayatım, s. 51.

61 Grivas, Hayatım, s. 51. 
bir örgütün varlığının tespit edildiğinden bahsediyordu. Buna rağmen İngiliz yönetimi adada ilave emniyet tedbirleri almak için ciddi bir girişim başlatmadı.

EOKA İngilizlerin el koyduğu patlayıcı malzemeleri, balıkçılardan ve madenlerde çalışan işçilerden çok miktarda patlayıcı temin ederek telafi etti. Takvimler mart sonunu gösterdiğinde beş veya altı kişilik sabotaj timlerinin beş büyük şehirde örgütlenmesi tamamlanmış ve ilk saldırı için planlanan saatin gelmesi için hazır halde bekletiliyorlardı. EOKA'nın en büyük avantajı adadaki İngiliz kuvvetlerinin hem yetersiz hem de düzensiz olmasıydı. Bu yüzden ada sathında güvenlik önlemleri oldukça yetersizdi. Polis silahsızdı ve karakollar arasında sıkı bir iletişim bulunmuyordu. Askerler Mısır'daki üsleri taşımakla ve yeni üsler inşa etmekle meşguldü. Sözün kısası ada terör eylemleri açısından gayet müsaitti. Grivas Makarios'tan 31 Mart gece yarısı ilk sabotajların yapılması için gerekli onayı aldı. Gece yarısı Lefkoşa, Limasol, Mağusa ve Episkopi'de büyük patlamalar meydana geldi. Hükümet radyo istasyonu, polis karakolları, elektrik santrali, Wolseley Kışlası ve mahkeme binası patlamaların hedef aldığı yerlerdi. Adada yaşayanlar 1 Nisan 1955 'te elden ele dolaşan bir bildiriyle Dighenis önderliğinde EOKA adlı bir örgütün İngiliz boyunduruğunu sonlandırmak amacıyla bir mücadele başlatmış olduğunu ilk kez öğrendiler.

\section{Sonuç}

EOKA, Enosis siyasetinin yürüdüğü olağan koşulların işlerlikten kalkma ihtimali düşüncesiyle İngiliz yönetimine karşı kurulmuş silahlı bir terör örgütü olarak tarih sahnesine girdi. Kırsalda gerilla savaşı, şehirlerde ise sabotajlar yapmak suretiyle iki koldan İngilizlere karşı yıldırma ve yıpratma stratejisi yürüttü. Bu terör eylemlerinin nihai hedefi adada hayatı her yönüyle felce uğratmak ve böylece sömürge idaresini Enosis konusunda dize getirmekti. Enosis talebinin, önce İngiltere'den, ardından Birleşmiş Milletler'den diplomasi yoluyla karşılanamaması, EOKA'nın kurulmasında belirleyici bir rol oynamıştır. Yunanistan'daki Papagos Hükümeti'nin kurulmasını açıkça desteklediği EOKA'nın gerek silahlı eylemlerinde gerekse de sokak gösterilerinde dünya kamuoyunun ilgisini üzerine çekebilmek maksadıyla genç yaştaki öğrencileri etkin bir şekilde kullandığı görülmüş̧ür.

EOKA her şeyden evvel Enosisi silah zoruyla gerçekleştirmek amacıyla kurulmuştur. Makalede de açıkça belirtildiği üzere başlangıçta, Enosisin gerçekleşmesinin önündeki tek engel olarak İngiltere görülmüştür. Başka bir ifadeyle EOKA'nın kuruluş planlamasının yapıldığı tarihlerde ne Kıbrıs Türkleri ne de Türkiye Enosis'e engel siyasi bir varlık şeklinde algılanmamıştır. Makarios, Grivas ve Papagos'un, adada düzenlenecek terör eylemleriyle oluşacak anarşik düzenin hem İngiltere hem de Birleşmiş Milletler 
tahtında kapanan Enosis diplomasisini yeniden canlandıracağını ümit ettikleri tespit edilmiştir. Fakat hiçbir zaman, adada oluşturulan anarşik düzenin Türkiye'yi Kıbrıs meselesine güçlü bir şekilde dâhil edebileceğini hesap etmedikleri fark edilmiştir.

Rumlara ve Yunanlılara göre EOKA, Kıbrıs'ın bağımsızlığını ve özgürlügüün̈ kazanması için mücadele eden kahraman bir örgüttür. Bu bakış açısından dolayı 1 Nisan tarihi, örgütün kuruluş yıldönümü olarak her yıl Güney Kıbrıs’ta dini ayinler ve ulusal etkinliklerle kutlanmaktadır. Aynı zamanda EOKA mücadelesinde hayatını kaybedenlerin sembolik heykellerin ve anıt mezarlarının yapıldığı bilinmektedir.

Hâlbuki EOKA’nın İngiliz sömürge idaresine karşı silahlı mücadeleye başvurma motivasyonunun hiçbir zaman bağımsızlık olmadığı çok açıktır. Zira örgütün amaçları arasında Enosis'in dışında bağımsızlık gibi alternatif bir çözüm modeline rastlamak imkânsızdır. Dolayısıyla örgütün Enosis dışındaki tüm seçeneklerden yalıtılmış olduğu söylenebilir. Ayrıca EOKA'nın sömürge yönetimini sonlandırmak amacıyla sömürge karşıtlarının bir araya gelerek oluşturdukları heterojen bir örgüt olmadığını da özellikle vurgulamak gerekiyor. Söz gelimi sömürge karşıtı komünistler ile Türkleri bu örgüt içerisinde görmek olası değildir. Nitekim Elen olmak, komünist olmamak ve Enosis taraftarlığı örgüte katılmanın asli şartları arasında yer alıyordu.

Hakem Değerlendirmesi: Dış bağımsız.

Çıkar Çatıșması: Yazar çıkar çatıșması bildirmemiștir.

Finansal Destek: Yazar bu çalışma için finansal destek almadığını beyan etmiştir.

Peer-review: Externally peer-reviewed.

Conflict of Interest: The author has no conflict of interest to declare.

Grant Support: The author declared that this study has received no financial support.

\section{KAYNAKÇA}

\section{Arşiv Belgeleri}

The National Archives, KV 2/3883: Gorgios GRIVAS: Greek. Leader of the military campaign in Cyprus for Enosis.

\section{Resmî Yayınlar}

Cypriot National Delegation, The Cyprus Plebiscite and The Greek Parliament London, 1950. 


\section{Süreli Yayınlar ${ }^{62}$}

Hürsöz (Kıbris)

Milliyet

\section{Araştırma Eserler}

Adams, T. W.: The Communist Party of Cyprus, Stanford, Hoover Intitution Press, 1971.

Beaton, Roderick: Greece: Biography of a Modern Nation, Chicago, Unversity of Chicago Press, 2019.

Clogg, Richard: Modern Yunanistan Tarihi, çev. Dilek Şendil, İstanbul, İletişim Yayınları, 1997.

Durrell, Lawrence: Kıbrıs'ın Acı Limonları, çev. Ülker İnce, İstanbul, Can Yayınları, 2007.

Foley, Charles, W.I., Scobie: The Struggle for Cyprus, Stanford, Hover Insttution Press, 1975. French, David: Fighting EOKA The British Counter-Insurgency Campaign on Cyprus 1955-1959, New York,Oxford Universty Press, 2015.

General Grivas: Hayatım, Ed. Charles Foley, çev. Cumhur Atay, İstanbul Kalkedon Yayınlar1, 2012.

Gürel, Şükrü S.: Kıbrıs Tarihi (1878-1960) 2, İstanbul, Kaynak Yayınları,1985.

Hill, George: Kıbrıs Tarihi 1571-1948, çev. Nazım Can Serbest, İstanbul, İş Bankası Yayınlar1, 2016.

Holland, Robert: Britain and the Revolt in Cyprus 1954-1959, New York, Oxford University Press, 1998.

İnalcık, Halil: "Helenizm, Megali İdea ve Türkiye”, Doğu Batı: Düşünce Dergisi, S. 31, 2005, s. 9-26.

Katsourides, Yiannos: The Greek Cypriot Nationalist Right in the Era of British Colonialism, Switzerland, Springer International Publishing, 2017.

Purcell, H. D.: Cyprus, New York, Frederick A. Praeger, 1969.

Smith, Michael Llewellyn: Yunan Düşü, çev. Halim İnal, Ankara, Ayraç Yayınevi, 2002. Vanezis, P.N.: Makarios: Pragmatism v. Idealism, London, Abelard-Schuman Limited, 1974. Volkan, Vamık D., Itzkowitz, Norman: Türkler ve Yunanlılar: Çatışan Komşular, çev.

Banu Büyükkal, İstanbul, Bağlam Yayınları, 2002.

Xydis, Stephen G.: "The UN General Assembly as an Instrument of Greek Policy: Cyprus, 1954-58”, The Journal of Conflict Resolution, Vol. 12, 1968, pp. 141-158.

62 Faydalanılan süreli yayınların tarih, makale/haber başlığı ve sayfa numaraları dipnotlarda belirtilmiştir. 
